\title{
Visualization of micromorphology of petal epidermal features of waxy and velvety flowers in Phalaenopsis
}

\author{
Wenfang Xiao, Zuo Li*, Heming Chen, Fubing Lv* $^{*}$ \\ Guangdong Key Laboratory of Ornamental Plant Germplasm Innovation and Utilization, \\ Environmental Horticulture Research Institute, Guangdong Academy of Agricultural Sciences, Guangzhou \\ 510640 China
}

*Corresponding authors, e-mail: lizuo8375@126.com, lvfubing@gdaas.cn

Received $10 \mathrm{Feb} 2020$

Accepted 3 Sep 2020

\begin{abstract}
Phalaenopsis, also known as moth orchids, are well known for their use as potted plants and high-grade cut flowers. The flower petals of Phalaenopsis have two specific natural textures, waxy and velvety. In order to look for the factors that affect the flower petal textures, in this study, scanning electron microscopy (SEM) and optical microscopy were used to observed, compared, and analyzed the cell shape and arrangement of petal epidermal cells among seven samples from Orchidaceae family, including six Phalaenopsis cultivars of different colors and optical textures, and one Paphiopedilum sample as the out-group. The observational results revealed that waxy petals were formed by parallel and tight arrangement of flat epidermal cells with relatively thick and smooth cuticles, whereas soft (velvety) petals were formed by independent and loose arrangement of conical epidermal cells with thin cuticles. This research showed that the petal epidermal cell structure and arrangement and the accumulation of cuticles directly affect the petal texture of Phalaenopsis germplasm, but not strongly relate to germplasm sources, floral color, floral stripe color, and floral size. The study could provide basic information for further studies on floral texture formation mechanisms in Phalaenopsis, and could provide more insight and evidence for directional breeding of ornamental traits in orchid.
\end{abstract}

KEYWORDS: Phalaenopsis, petal texture, scanning electron microscopy, optical microscope, epidermal cell structure

\section{INTRODUCTION}

Phalaenopsis, commonly known as moth orchids, are well known for their use as potted plants and high-grade cut flowers. The flower petals of Phalaenopsis have two specific natural textures, waxy (glossy) and velvety (papery), meanwhile those waxy petals are thicker and harder than velvety petals in the conventional breeding and cultivation experience. In this study, we looked at the factors that affect the petal textures. As the current ornamental flowers on the market usually have thin and velvety petals, the introduction of thick and waxy flowers largely meets the diverse needs of consumers, bringing a novel visual and tactile experience. As they have petals with a hard texture, waxy flowers are able to be transported over longdistance and can be preserved for a longer time; they are becoming more and more popular on the flower market. However, studies $[1,2]$ on the relationship between floral texture differences and petal epidermal cellular microtextures have provided insight for further studies of inheritance and defense mechanisms between different floral textures.
Plants can defend themselves against insects by forming epidermis of different smoothness at different parts. For example, some plants have smooth waxy surfaces that avoid adhesion of insects, whereas in the pitcher plant, the waxy surface of its pitcher attracts insects; and the waxy surface of its stem and flowers prevents insects from eating nectar. Some chemical components of waxy surfaces act as deterrents for insects [3]. As a major reproductive organ of angiosperms, flowers are conservative in plant systematic phylogeny, and have an important role in plant systematics. In recent years, studies of flowers have mainly focused on floral morphology and morphogenesis, and the results of these studies provided crucial information about the relationships between different plant species. Another study [4] used scanning electron microscopy (SEM) to observe petal epidermal types in angiosperms and proposed that different petal epidermal types are helpful for the systematic classification of plants. A recent study on the differences in floral development of the two species of Lycoris, widely used in gardening and medicine, has been reported which may be useful in the hybridization, breeding and 
regulation of flowering of these plants [5].

Floral texture is an important ornamental characteristic, and is also an important breeding trait of high ornamental and economic values. Previous studies regarding the floral textures of ornamental flowers found that different textures could generate distinct visual effects, such as metallic luster, velvet luster and diamond dust, which increase both the value of ornamental plants and the color diversity of flowers $[1,2]$. Different floral textures can increase the diversity of petal types and can be an important trait for breeding new cultivars. Current breeding studies in ornamental flowers mainly focus on the selective breeding of floral colors with no concern for texture traits. Light reflected from the petal surface and observed by the naked eye can affect the formation of floral textures and present different visual effects. Previous Studies [6-8] also demonstrated that the light reflected from the petal surface was affected by epidermal cell shape. And in another orchid study [9] of petals from 34 cultivars and varieties in the Dendrobium genus determined their color intensity, color ratio, and visual quality by investigating the roles of floral pigment distribution and shapes of epidermal cells. Moreover, the largest previous study on the petal structure of 201 angiosperm species from 60 families [10] and investigating into the majority of the germplasm resources ( 85 out of 97) found that the epidermal cells of most petals had either a dome or conical cell wall. It was also discovered that there are six basic types of petal epidermis, based on anatomical structure. Sometimes, the petal epidermis presents with a mixture of more than one anatomical type.

The naturally differentiated features of floral textures can provide more options for cross breeding, such as selective breeding of new cultivars with waxy flowers (or flowers with thicker petals). Current studies regarding the inheritance of important floral traits mainly focus on color, shape, and fragrance, but the unique trait of waxy flowers is only present in some ornamental flower species, such as Chimonanthus praecox (L.) Link and Camellia chrysantha (Hu) Tuyama. Due to the limitation of study materials, the principles and mechanisms of inheritance of floral textures are poorly understood. Nonetheless, there have been a number of studies regarding leaf surfaces or epidermis cells of plants [11-17]. Therefore, as the most reproductive and ornamental organ in plants, flowers have significant economic value, and our study of floral textures is biologically significant and has longterm commercial value. In this study, we selected waxy flower material of three typical colors from our previously established Phalaenopsis germplasm bank and then selected velvety flowers with the corresponding colors. We then selected waxy flower material from Paphiopedilum, a different genus in the Orchidaceae family, as the out-group. Using SEM and optical microscopy, we observed, compared, and analyzed the cell shape and arrangement of petal epidermal microstructures and cross section, and we identified factors that affect differences in floral texture. This study can provide basic information for further studies on floral texture formation mechanisms in Phalaenopsis, and can provide more insight and evidence for directional breeding of ornamental traits in Phalaenopsis.

\section{MATERIALS AND METHODS}

\section{Plant materials}

In this study, the inflorescences were selected from seven orchid samples. Ten replicated samples were taken each from six Phalaenopsis cultivars of different colors and optical textures. Ten replicated samples of the Paphiopedilum germplasm were used, another genus in the Orchidaceae family. All samples contained petals of both waxy and velvety textures and of three typical colors, fuchsia, yellow, and white. Due to a lack of orchid germplasm with pure white waxy flowers, all the white waxy petal samples were excised from the white part of the petal edges of Phalaenopsis cultivar '866' (Fig. 1c). Morphological characterization was executed in accordance with the type of petal and flowers following International Union for the Protection of New Varieties of Plants (UPOV) guidelines [18]. (See Table 1 for the description of morphological features of these samples and Fig. 1 for the images of their floral morphological features.)

\section{Scanning electron microscopy of petal epidermal cell surfaces}

To observe the petals epidermis, immersion fixation procedure was used in this project: the fresh petals from the 4th or 5th day of blooming flower were selected and used, and the central parts of fresh petals were cut (approx. $0.5 \times 0.5 \mathrm{~mm}$ square) and immediately immersed in $2.5 \%(\mathrm{v} / \mathrm{v})$ glutaraldehyde solution at $4{ }^{\circ} \mathrm{C}$ overnight, and washed with phosphate buffer solution ( $\mathrm{pH}$ 7.2) for 3 times, $10 \mathrm{~min}$ for each time. Then the petal samples were dehydrated once and $10 \mathrm{~min}$ each, in a graded ethanol series: $30 \%$, $50 \%, 70 \%, 90 \%, 95 \%$, and $100 \%$. The samples were further treated twice with isoamyl acetate for 

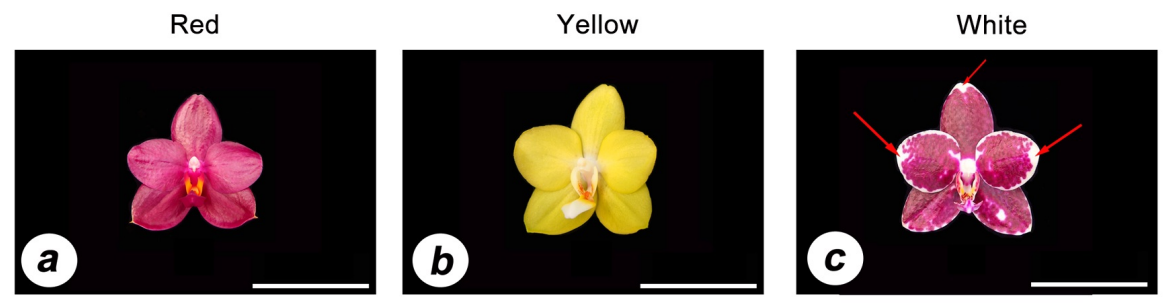

Waxy Phalaenopsis
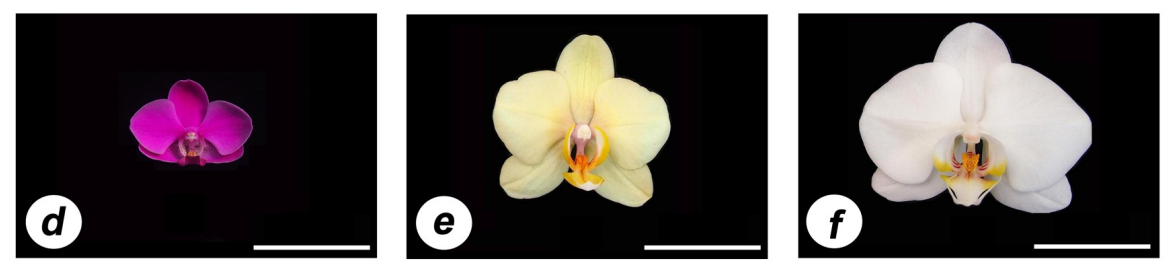

Velvety Phalaenopsis

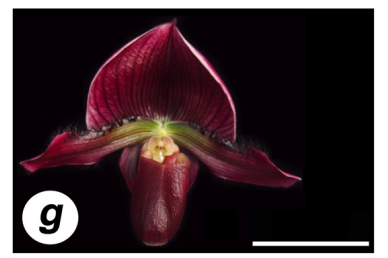

Waxy Paphiopedilum

Fig. 1 Photograph illustrating the texture and colour differences of petal surfaces of the six Phalaenopsis tested samples and one Paphiopedilum as an out-group sample. (a) Phalaenopsis cultivar 'YHP-019', pure red-waxy petals; (b) Phalaenopsis cultivar '657', pure yellow-waxy petals; (c) Phalaenopsis cultivar '866', the red arrows point to the pure white-waxy petal margin sections which were sampled in this project; (d) Phalaenopsis Queen Beer 'Mantefon', pure red-velvety petals; (e) Phalaenopsis cultivar '873', pure yellow-velvety petals; (f) Phalaenopsis 'Sogo Yukidian', pure white-velvety petals; (g) Paphiopedilum Maudiae, pure red-waxy lip. Bar $=5 \mathrm{~cm}$.

Table 1 Seven Orchid accessions used in the present study.

\begin{tabular}{|c|c|c|c|c|c|c|c|}
\hline \multirow[b]{2}{*}{ Code } & \multirow[b]{2}{*}{ Species } & \multicolumn{6}{|c|}{ Characteristics of flower } \\
\hline & & $\begin{array}{l}\text { Petal texture } \\
\text { (waxy/ } \\
\text { velvety) }\end{array}$ & $\begin{array}{l}\text { Thickness } \\
\text { of petal } \\
(\mathrm{mm})^{\mathrm{a}}\end{array}$ & $\begin{array}{l}\text { Width in } \\
\text { front view of } \\
\text { flower }(\mathrm{cm})^{\mathrm{a}}\end{array}$ & $\begin{array}{l}\text { Length in front } \\
\text { view of flower } \\
(\mathrm{cm})^{\mathrm{a}}\end{array}$ & $\begin{array}{l}\text { Flower main } \\
\text { color }\end{array}$ & $\begin{array}{l}\text { RHS color chart } \\
\text { no. }\end{array}$ \\
\hline 1 & $\begin{array}{l}\text { Phalaenopsis } \\
\text { cultivar 'YHP-019' }\end{array}$ & waxy & $1.35 \pm 0.09$ & $6.19 \pm 0.37$ & $6.21 \pm 0.65$ & Fuchsia & $\begin{array}{l}\text { PURPLE GROUP } \\
\text { N78-A }\end{array}$ \\
\hline 2 & $\begin{array}{l}\text { Phalaenopsis } \\
\text { cultivar ' } 657 \text { ' }\end{array}$ & waxy & $1.21 \pm 0.13$ & $6.23 \pm 0.46$ & $6.45 \pm 0.71$ & Yellow & $\begin{array}{l}\text { GREEN-YELLOW } \\
\text { GROUP 1-A }\end{array}$ \\
\hline 3 & $\begin{array}{l}\text { Phalaenopsis } \\
\text { cultivar '866' }\end{array}$ & waxy & $1.25 \pm 0.10$ & $6.08 \pm 0.34$ & $6.35 \pm 0.40$ & $\begin{array}{l}\text { White part (excised } \\
\text { from the white petal } \\
\text { edges) }\end{array}$ & $\begin{array}{l}\text { WHITE GROUP } \\
\text { NN155-A }\end{array}$ \\
\hline 4 & $\begin{array}{l}\text { Phalaenopsis Queen } \\
\text { Beer 'Mantefon' }\end{array}$ & velvety & $0.58 \pm 0.04$ & $5.43 \pm 0.27$ & $3.54 \pm 0.17$ & Fuchsia & $\begin{array}{l}\text { RED-PURPLE } \\
\text { GROUP 72-A }\end{array}$ \\
\hline 5 & $\begin{array}{l}\text { Phalaenopsis } \\
\text { cultivar '873' }\end{array}$ & velvety & $0.85 \pm 0.10$ & $8.46 \pm 0.46$ & $7.85 \pm 0.69$ & Yellow & $\begin{array}{l}\text { GREEN-YELLOW } \\
\text { GROUP 1-D }\end{array}$ \\
\hline 6 & $\begin{array}{l}\text { Phalaenopsis 'Sogo } \\
\text { Yukidian' }\end{array}$ & velvety & $0.85 \pm 0.10$ & $10.32 \pm 0.64$ & $8.13 \pm 0.83$ & White & $\begin{array}{l}\text { WHITE GROUP } \\
\text { NN155-D }\end{array}$ \\
\hline 7 & $\begin{array}{l}\text { Paphiopedilum Mau- } \\
\text { diae }\end{array}$ & waxy & $0.68 \pm 0.05$ & $12.29 \pm 0.61$ & $10.42 \pm 0.98$ & Fuchsia & $\begin{array}{l}\text { GREYED-PURPLE } \\
\text { GROUP 187-B }\end{array}$ \\
\hline
\end{tabular}

${ }^{\text {a }}$ Data are mean \pm SD $(n=10)$

b Flower color: All samples' color was measured in the absence of direct sunlight using the Royal Horticultural Society (RHS) colour chart. 
15 min each time. Then the samples were dried in a critical point drier (CPD 030; BAL-TEC Inc., Balzers, Liechtenstein) with liquid carbon dioxide as a transitional fluid. Samples were mounted on metal stubs, sputter-coated with gold, and adaxial surface of all the samples were examined under a Scanning Electron Microscopes (SEM) (XL-30ESEM, FEI, Holland). The terminology of epidermis morphology suggested by previous researches was adopted in this study $[2,14,19]$.

\section{Preparation of petal tissue sections and observation of anatomical structure}

Fresh petals were collected and washed with distilled water immediately from the 4th or 5th day of blooming flower. For microscopic observation, transverse sections were prepared by following the method detailed by Mudalige et al [9], fresh petal parts (approx. 0.1-0.2 mm thickness) were sectioned using a sharp razor blade, and immersed in $0.25 \%$ polyethylene glycol solution (M.W. 4000), and then observed using a Zeiss Axio Scope A1 microscope.

\section{RESULTS}

\section{Epidermal cell structure features of waxy and velvety petals of different colors under SEM}

All petals used in this study were of pure color. This ensured that features of the epidermal cell structure could be better compared between Phalaenopsis petals with different textures. It also avoided the interference of any stripes on the petals. First, the differences in adaxial epidermal structure between waxy petals (Fig. 2(a,b,c)) and velvety petals (Fig. 2(d,e,f)) were compared using SEM. In this experiment, petals of three typical colors (fuchsia, yellow, and white) were observed. The observation results showed that the adaxial epidermis surface and cell arrangement is not related to floral color but to floral texture. The waxy petals of different colors in these Phalaenopsis observed samples all showed consistent adaxial epidermis surface and cell arrangement: flat and irregular shaped, parallel and tightly arranged, and no intercellular gaps. The epidermal cells of velvety flowers were conical (or dome) shaped, loosely arranged, and with a large number of intercellular gaps. Furthermore, the epidermal cell structure and arrangement of Paphiopedilum waxy petals (Fig. $2 \mathrm{~g}$ ) were consistent with those of Phalaenopsis waxy petals.

\section{Differences in shape and arrangement of epithelial cells between waxy and velvety petals of different colors under optical microscope}

Under SEM, only the horizontal structure and arrangement of petal epidermal cells can be observed. The vertical cell structure can be observed using the cross section of fresh petal slices. Microscopic observation of six Phalaenopsis samples showed the presence of three types of epidermal cells: square, conical-papillate, and rounded-conical (Fig. 3). The epidermal cells of the three waxy petal samples were all flat (Fig. 3(a,b,c)), whereas the velvety petals only had conical cells, such as conical-papillate (Fig. 3(d,f)) and rounded-conical (Fig. 3e). In addition, square-type epidermal cells were also present in the waxy petals of Paphiopedilum. These results revealed that the cell shape and arrangement only contribute to floral texture, but are not related to floral color. However, the variation in pigment related to petal color. Meanwhile, the observational results of vertical epidermal cell structure were consistent with the horizontal cell structure.

The relationship between epidermal microstructure and morphological features of petals

In the two experiments above, we found that the shape and arrangement of petal epidermal cells are closely related to petal morphology in Phalaenopsis. Observation by naked eye revealed that under the same lighting conditions, waxy petals all presented with surface reflection and had a thick oily tactile quality; whereas velvety flowers presented with no surface reflection, and had a thin soft tactile quality. Measurement of Phalaenopsis petal thickness also showed that waxy petals were thicker than velvety petals (Table 1). In addition, the waxy lip of $\mathrm{Pa}$ phiopedilum had morphological features that were consistent with the waxy petals of Phalaenopsis, with greater surface reflection observed and a more pronounced feeling of oiliness. The six Phalaenopsis samples used in this study all had different floral sizes and colors, but both experiments revealed that the petal epidermal cell structure is only closely related to floral texture. It was observed from this study that the thickness of petal was formed by the petal epidermal cell structure and arrangement and the accumulation of cuticle, which was directly related to the texture of petal of Phalaenopsis germplasm. 

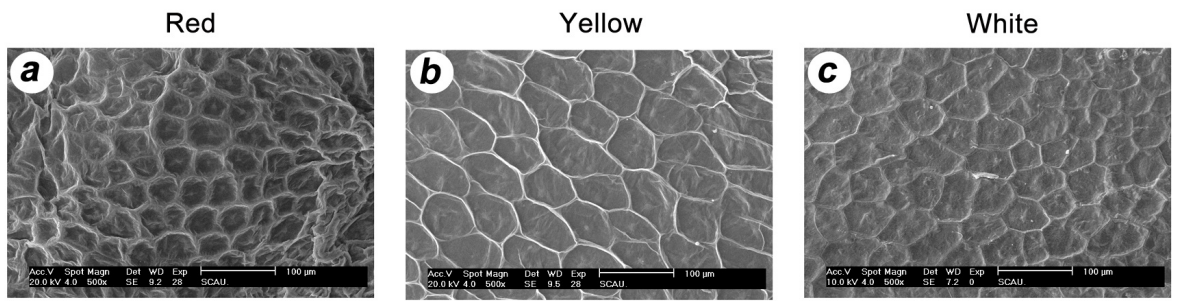

Waxy Phalaenopsis
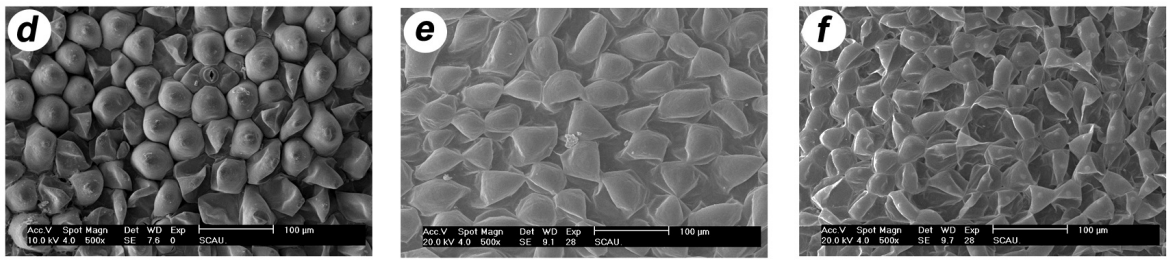

Velvety Phalaenopsis

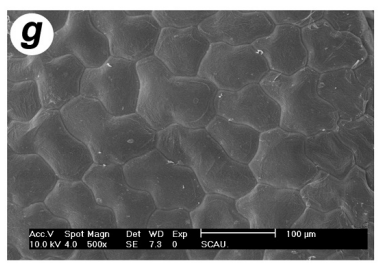

Waxy Paphiopedilum

Fig. 2 Scanning electron micrographs of the adaxial petal epidermis of the six Phalaenopsis tested samples and one Paphiopedilum out-group sample. (a) Flat cells of Phalaenopsis cultivar 'YHP-019'; (b) Flat cells of Phalaenopsis cultivar '657'; (c) Flat cells of Phalaenopsis cultivar '866'; (d) Cone-shaped cells of Phalaenopsis Queen Beer 'Mantefon'; (e) Domeshaped cells of Phalaenopsis cultivar '873'; (f) Small dome-shaped cells of Phalaenopsis 'Sogo Yukidian'; (g) Flat cells of Paphiopedilum Maudiae. Bar $=100 \mu \mathrm{m}$.

\section{DISCUSSION}

In this study, we compared the differences in petal epidermal microtexture between waxy and velvety flowers of Phalaenopsis, and we investigated the factors that affect petal texture, according to epidermal features.

Based on the results of this study and a preliminary observation study of petal epidermis between native and cultivated Phalaenopsis [20], we found that the epidermal cell structure and arrangement are not related to germplasm sources, floral color, or floral stripe color. Most of the waxy flowers in our Orchid Germplasm Nursery are medium-sized or small-sized; therefore, we selected a small-sized velvety flower cultivar (Fig. 1d); a medium-sized velvety flower cultivar (Fig. 1e); and a large-sized velvety flower cultivar (Fig. 1f). The observation results revealed that the waxy flowers of similar size showed consistent features of petal epidermal cell structure, and the three velvety flower cultivars all exhibited the same pattern of petal epidermal cell structure.

Our study has shown that waxy petals were formed by parallel and tightly arranged flat epi- dermal cells with relatively thick, smooth cuticles; whereas soft (velvety) petals were formed by independent loosely arranged conical epidermal cells with thin cuticles. Similar results were shown in a previous study of epidermal cell morphology of Dendrobium [9], which demonstrated that the shape and natural features of the mesophyll layers in epidermal cells mutually affected the visual quality of flowers. Square cells with relatively thick, smooth cuticles and tightly arranged mesophyll tissues with few intercellular gaps mutually contributed to the smooth texture of flowers; whereas thin cuticles and loosely arranged mesophyll tissues with large intercellular gaps mutually contributed to the softness of velvety flowers [9]. Other previous studies also had similar results; conical cells seem to be universally present in some orchid species, such as Anacamptis pyramidalis, Dactylorhiza fuchsii [10], and many species of Cattleya and Laelia [21]. In particular, observation of Cattleya flowers [21,22] demonstrated that smooth petals had square epidermal cells; whereas velvety petals had triangular epidermal cells with a greater height-to-width ratio. Matsui [21, 22] hypothesized that the shape and size 

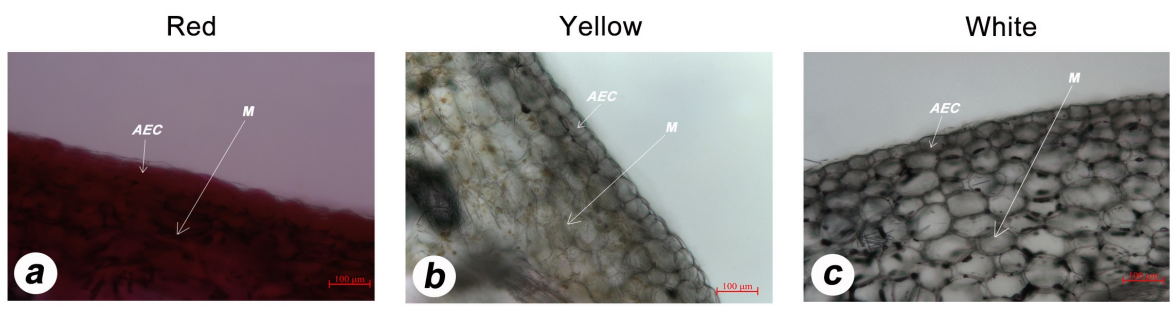

Waxy Phalaenopsis
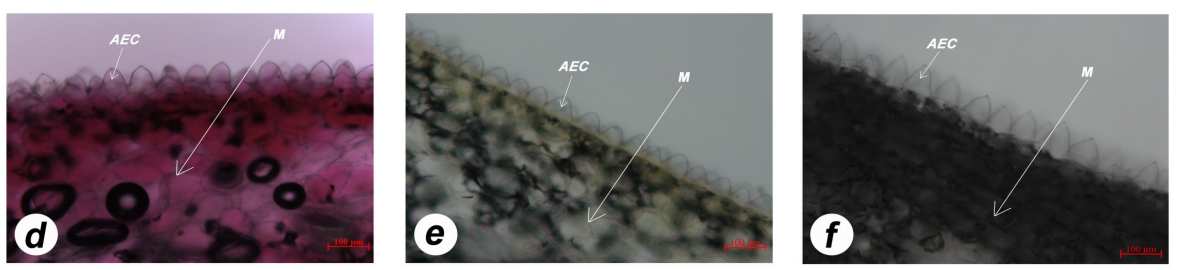

Velvety Phalaenopsis

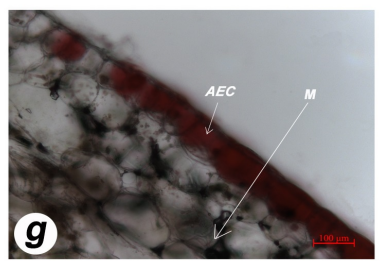

Waxy Paphiopedilum

Fig. 3 Transverse sections of the adaxial petal epidermis of the six Phalaenopsis tested samples and one Paphiopedilum out-group sample. (a) Square cells of Phalaenopsis cultivar 'YHP-019'; (b) Square cells of Phalaenopsis cultivar '657'; (c) Square cells of Phalaenopsis cultivar '866'; (d) Conical-papillate cells of Phalaenopsis Queen Beer 'Mantefon'; (e) Rounded-conical cells of Phalaenopsis cultivar '873'; (f) Conical-papillate cells of Phalaenopsis 'Sogo Yukidian'; (g) Square cells of Paphiopedilum Maudiae. Bar $=100 \mu \mathrm{m}$. AEC $=$ adaxial epidermal cell, $\mathrm{M}=$ mesohyll.

of epidermal cells, particularly the height-to-width ratio of cells, could affect floral texture. Further investigation into more flower materials of other genera and species in the Orchidaceae family is required to determine whether this is the common feature of floral texture formation in orchid plants.

As Phalaenopsis has natural differentiation of floral texture, and has germplasm resources of both waxy and velvety flowers, it could be suggested as a model plant material for comparative studies of floral textures among different species in the Phalaenopsis genus, and for comparative studies of floral textures among other families and genera. In our study, the same texture could be found on both fuchsia and white colored petals. However, in one previous study [2] on selected ornamental flower materials included petals with a velvet luster texture and non-velvety texture showed that velvety petals had two common features, conical-papillate or dome shaped epidermal cells and dark colors. Moreover in our study, we only found waxy and soft velvety petals. The key factors that affect floral texture were cell shape and arrangement, and such floral texture differentiation exists both in petals of dark colors, with high pigment content, and light colors, with low pigment content. However, another study of color diversity and functional optics ${ }^{1}$ listed three typical floral textures, namely: velvet luster (e.g., Viola tricolor), generated by surfacereflected light; metallic luster (e.g., Begonia rex), generated by scattered light; and diamond dust (e.g., Saintpaulia ionantha). The study proposed that the key factors that affect floral texture are two types of surface reflected light, which are affected by different epidermal cell shapes and petal structure.

Furthermore, a previous study of buttercup ( $R a$ nunculus spp.) flowers [23] revealed that in addition to matte yellow flowers with little smoothness, buttercup also has yellow flowers with mirror-like reflectiveness. Using microscopic spectrophotometry and anatomical approaches, the researchers discovered the optical features of waxy flowers. The results showed that the waxy flower was formed by a rare structure and combination of pigmentation; very flat epithelial layer full of pigments, making the flowers appear waxy like a thin-film reflector. In our study of Phalaenopsis petals, we discovered similar waxy textures, not only in yellow petals, but also in petals of all three colors that exhibit the parallel and tightly arranged flat-type of epidermal 
cells. Currently, there has been no evidence in plants of other families showing a similar phenomenon of floral texture differentiation within the same species. An important question would be whether this phenomenon is unique to Orchidaceae.

Due to a shortage of plant materials with waxy flowers, there are still many floral texture formation mechanisms that are poorly studied. The wax morphology is well studied in plant leaves and peels [24-27]. In terms of describing different leaf textures, generally they were described as thin, soft leaves as velvety, and thick, hard leaves as leathery [15]. However, there is still no unified criterion for describing floral texture as an important ornamental trait. In related research monographs and publications $[18,28,29]$, different scholars used different words to describe floral textures. For example, waxy or glossy is used to describe flowers with hard, thick and smooth texture; whereas velvety or papery or membranous is used to describe flowers with soft, thin and light texture. Therefore, further investigation is still required to determine whether the waxy components are similar among floral epidermis and whether leaves have similar waxy components, in addition to whether they have similar cell structural patterns. Researchers should also work together to find out whether a universal definition should be used, such as waxy for the description of smooth and shiny floral textures; and velvety for the description of soft, thin film-like floral textures that do not reflect light.

In conclusion, the petal epidermal cell structure and arrangement and the accumulation of cuticle directly affect the texture of petal of Phalaenopsis germplasm, but not strongly related to germplasm sources, floral color, floral stripe color and floral size.

Acknowledgements: This research was supported by the Key Areas Research and Development Program of Guangdong Province of China (grant no. 2018B020202001) and the Guangzhou Municipal Science and Technology Program (grant no. 201807010092). The experiment was performed at the Guangdong Key Laboratory of Ornamental Plant Germplasm Innovation and Utilization, Guangzhou, China. We thank TopEdit for its linguistic assistance during the preparation of this manuscript.

\section{REFERENCES}

1. Zhang Y, Hayashi T, Inoue M, Oyama Y, Hosokawa M, Yazawa S (2008) Flower color diversity and its optical mechanism. Acta Hort 766, 469-475.
2. Zhang Y, Sun TX, Xie LN, Hayashi T, Kawabata S, Li YH, (2015) Relationship between the velvet-like texture of flower petals and light reflection from epidermal cell surfaces. J Plant Res 128, 623-632.

3. Eigenbrode SD (2004) The effects of plant epicuticular waxy blooms on attachment and effectiveness of predatory insects. Arthropod Struct Dev 33, 91-102.

4. Christensen KI, Hansen HV (1998) SEM-studies of epidermal patterns of petals in the angiosperms. Opera Botanica 135, 5-86.

5. Cai J, Fan J, Wei X, Zhang D, Ren J, Zhang L (2020) Differences in floral development between Lycoris radiata and Lycoris sprengeri. ScienceAsia 46, 271-279.

6. Noda K, Glover BJ, Linstead P, Martin C (1994) Flower colour intensity depends on specialized cell shape controlled by a Myb-related transcription factor. Nature 396, 661-664.

7. Glover BJ, Martin C (1998) The role of petal cell shape and pigmentation in pollination success in Antirrhinum majus. Heredity 80, 778-784.

8. Gorton HJ, Vogelmann TC (1996) Effects of epidermal cell shape and pigmentation on optical properties of Antirrhinum petals at visible and ultraviolet wavelengths. Plant Physiol 112, 879-888.

9. Mudalige RG, Kuehnle AR, Amore TD (2003) Pigment distribution and epidermal cell shape in Dendrobium species and hybrids. Hortscience 38, 573-577.

10. Kay QON, Daoud HS, Stirton CH (1981) Pigment distribution, light reflection and cell structure in petals. Bot J Linn Soc 83, 57-84.

11. Glover BJ (2000) Differentiation in plant epidermal cells. J Exp Bot 51, 497-505.

12. Beattie GA, Marcell LM (2002) Effect of alterations in cuticular wax biosynthesis on the physicochemical properties and topography of maize leaf surfaces. Plant Cell Environ 25, 1-16.

13. Baumann K, Perez-Rodriguez M, Bradley D, Venail J, Bailey P, Jin H, Koes R, Roberts K, et al (2007) Control of cell and petal morphogenesis by R2R3 MYB transcription factors. Development 134, 1691-1701.

14. Kim KW (2008) Visualization of micromorphology of leaf epicuticular waxes of the rubber tree Ficus elastica by electron microscopy. Micron 39, 976-984.

15. Zhang Y, Hayashi T, Hosokawa M, Yazawa S, Li Y (2009) Metallic lustre and the optical mechanism generated from the leaf surface of Begonia rex Putz. Sci Hortic-Amsterdam 121, 213-217.

16. Yin Y, Bi Y, Chen SJ, Li YC, Wang Y, Ge YH, Ding B, Li YC, et al (2011) Chemical composition and antifungal activity of cuticular wax isolated from Asian pear fruit (cv. Pingguoli). Sci Hortic-Amsterdam 129, 577-582.

17. Whitney HM, Poetes R, Steiner U, Chittka L, Glover BJ (2011) Determining the contribution of epidermal cell shape to petal wettability using isogenic Antirrhinum lines. PLoS One 6, e17576. 
18. International Union for the Protection of New Varieties of Plants (UPOV) (2003) Phalaenopsis (Phalaenopsis Blume)-Guidelines for the conduct of tests for distinctness, uniformity and stability. Geneve.

19. Hsieh MH, Lu HC, Pan ZJ, Yeh HH, Wang SS, Chen WH, Chen HH (2013) Optimizing virus-induced gene silencing efficiency with Cymbidium mosaic virus in Phalaenopsis flower. Plant Sci 201-202, 25-41.

20. Li Z, Xiao WF, You Y, Chen HM, Lv FB (2014) Study on petal morphology of Phalaenopsis by SEM. Adv Ornamental Hortic Chin, pp 180-184.

21. Matsui S (1990) Flower pigment distribution in perianth of Cattleya and allied genera. In: Kimura T, Ichihashi S, Nagata H (eds) Proc of the Nagoya Intl Orchid Show'90, Nagoya, Japan, pp 169-172.

22. Matsui S (1992) Inheritance of distribution patterns of flower pigment and shape of its epidermal cells in Cattleya and allied genera. In: Ichihashi S, Nagata $\mathrm{H}$ (eds) Proc of the Nagoya Intl Orchid Show'92, Nagoya, Japan, pp 117-122.

23. van der Kooi CJ, Elzenga JTM, Dijksterhuiss J,
Stavenga DG (2017) Functional optics of glossy buttercup flowers. $J$ R Soc Interface 14, ID 20160933.

24. Barthlott W, Neinhuis C, Cutler D, Ditsch F, Meusel I, Theisen I, Wilhelmi H (1998) Classification and terminology of plant epicuticular waxes. Bot J Linn Soc 126, 237-260.

25. Klimko M, Truchan M (2006) Morphological variability of the leaf epidermis in selected taxa of the genus Ficus L. (Moraceae) and its taxonomical implications. Acta Soc Bot Pol 75, 309-324.

26. Sonibare MA, Jayeola AA, Egunyomi A, Murata J (2005) A survey of epidermal morphology in Ficus Linn. (Moraceae) of Nigeria. Bot Bull Acad Sinica 46, 231-238.

27. Storey R, Price WE (1999) Microstructure of the skin of d'Agen plums. Sci Hortic-Amsterdam 81, 279-286.

28. Christenson EA (2001) Phalaenopsis: A Monograph, Timber Press, Inc., Portland, Oregon, USA.

29. Frowine SA (2008) Moth Orchids: The Complete Guide to Phalaenopsis, Timber Press, Inc, Portland, Oregon, USA. 